\title{
PENGUKURAN RISIKO OPERASIONAL PADA BANK SYARIAH INDONESIA (STUDI KASUS BANK SYARIAH XYZ)
}

\author{
OPERATIONAL RISK MEASUREMENT OF ISLAMIC BANK IN INDONESIA \\ (A CASE STUDY OF XYZ ISLAMIC BANK)
}

\author{
Yudi Yudiana ${ }^{* 1}$, Didin Hafidhuddin**), dan Rifki Ismal**) \\ *) PT Bank Muamalat Indonesia, Tbk \\ Jl. Prof Dr Satrio, Kav. 18 Kuningan Timur, Setiabudi Jakarta Selatan 12940 \\ **) Universitas Ibn Khaldun (UIKA) \\ Jl. Baru, Kedung Badak, Tanah Sereal, Bogor 16162 \\ ${ }^{* * *}$ Departemen Ekonomi dan Keuangan Syariah Bank Indonesia (BI) \\ Jl. MH. Thamrin No.2 Jakarta Indonesia 10350
}

\begin{abstract}
The research aimed at calculating the Operational Value at Risk (OpVar) in estimating the probability of the frequency of losses at Sharia Bank of XYZ, analyzing and assessing the event types of operational risks which have a great contribution in the operational losses of the bank, and determining the efficiency levels of the operational value at risk of capital charges of the bank. Measurement of operational risk in this study was conducted using the Loss Distribution Approach (LDA) Aggregated Model, as one of the Advanced Measurement Approach (AMA) models, which theoretically produces more efficient capital charges. The results showed that the contribution of the biggest losses came from the events of business disruption and system failure, execution, delivery \& process management and internal fraud. The calculation of the operational risk of the bank conducted using the LDA-Aggregate produced lower capital charges than those using the Basic Indicator Approach.
\end{abstract}

Keywords: Islamic bank, operational risk measurement, advanced measurement approach, loss distribution approach

\begin{abstract}
Abstrak: Penelitian ini bertujuan melakukan perhitungan Operational Value at Risk $(\mathrm{OpVaR})$ untuk mengestimasi peluang kejadian kerugian (probability of the frequency of losses) di bank syariah xyz; menganalisis dan mengevaluasi tipe kejadian risiko operasional yang berkontribusi besar pada kerugian operasional bank syariah xyz; menentukan besarnya tingkat efisiensi beban modal risiko operasional bank syariah xyz. Pengukuran risiko operasional dalam penelitian ini menggunakan Loss Distribution Approach (LDA) Aggregated Model sebagai salah satu internal model Advanced Measurement Approach (AMA) yang secara teori menghasilkan beban modal yang lebih efisien. Hasil penelitian menunjukkan kerugian terbesar terdapat pada tipe kejadian business disruption \& system failure, execution, delivery \& process management dan internal fraud. Perhitungan risiko operasional bank syariah xyz dengan menggunakan Metode LDA-Aggregate menghasilkan beban modal yang lebih rendah dibandingkan dengan penggunaan metode Basic Indicator Approach.
\end{abstract}

Kata kunci: bank syariah, pengukuran risiko operasional, advanced measurement approach, loss distribution approach

\footnotetext{
${ }^{1}$ Alamat Korespondensi:

Email: yudiana.yudi@gmail.com
} 


\section{PENDAHULUAN}

Berbeda dengan risiko kredit dan risiko pasar, risiko operasional bank syariah memiliki karakteristik yang unik selain disebabkan orang, sistem dan teknologi, proses dan kebijakan, faktor eksternal, juga karena terekspos Sharia Non-Compliance Risk, Fiducia Risk, People Risk dan Legal Risk (Izhar dan Asutay, 2010). Risiko operasional merupakan salah satu risiko yang wajib diperhitungkan bank dalam menghitung ATMR (BI, 2009). Pengukuran risiko operasional bank syariah xyz selama ini menggunakan metode Basic Indicator Approach (BIA), yaitu tingkat risiko operasional sebesar $15 \%$ dari rata-rata tahunan gross income positif selama tiga tahun terakhir. Dalam menentukan profil risiko, pendekatan ini dianggap masih kurang tepat, karena masih menghitung skala usaha bank terhadap besarnya risiko operasional yang dihadapi, selain tidak adanya pencadangan yang dibentuk untuk tipe kejadian, frekuensi terjadinya dan pengendalian internal bank dimana bank beroperasi (Global Assosiation of Risk Professionals, 2008). Kuhn (2002) mengatakan manajemen risiko pada bank didasari pada dua diversifikasi, hedging dan equity capital sebagai loss buffer. Kerugian tidak terduga yang tidak terdiversifikasi atau terlindungi nilainya (hedged), ditutupi oleh modal ekuitas bank. Berapa banyak modal bank diperlukan untuk menutupinya, ditentukan oleh apa yang disebut Value at Risk (VaR). Tujuan dari analisis VaR adalah untuk memberikan memberikan batasan kuantitatif untuk menetapkan jumlah reserve atau kebutuhan modal dalam mengatasi potensi kerugian (Gourieroux et al. 2000). Perbandingan cadangan modal risiko operasional terhadap kerugian risiko operasional selama kurun waktu tiga tahun terakhir di bank syariah xyz mengalami tren peningkatan namun tidak sebanding secara proporsional dengan kerugian operasional riil.

Dalam Gambar 1 terlihat penurunan kerugian operasional riil di tahun 2014 justru diimbangi dengan kenaikan cadangan modal risiko operasional, artinya alokasi cadangan modal risiko operasional yang selama ini dilakukan belum memperhitungkan risiko yang sebenarnya sehingga strategi bisnis bank menjadi kurang fleksibel. Perhitungan dengan model internal LDA-Aggregation sebagai salah satu metode perhitugan Advanced Measurement Approach (AMA) diharapkan akan lebih dapat menggambarkan profil kerugian yang lebih sensitif terhadap risiko dan beban modal risiko operasional yang lebih efisien bagi bank syariah xyz, karena apabila beban modal yang dicadangkan besar akan memengaruhi Capital Adequacy Ratio (CAR) serta kemampuan bank dalam melaksanakan fungsi intemediasi. Seperti terlihat dalam Gambar 2, CAR bank syariah xyz telah mengalami tren penurunan. Islamic Financial Services Board (2005) menetapkan bahwa modal minimum untuk menutup risiko operasional adalah $8 \%$. Namun, negara anggota dapat menetapkan CAR lebih tinggi dari 8\%. Di Indonesia regulator perbankan telah menetapkan CAR minimum sebesar 8\% (BI, 2009).

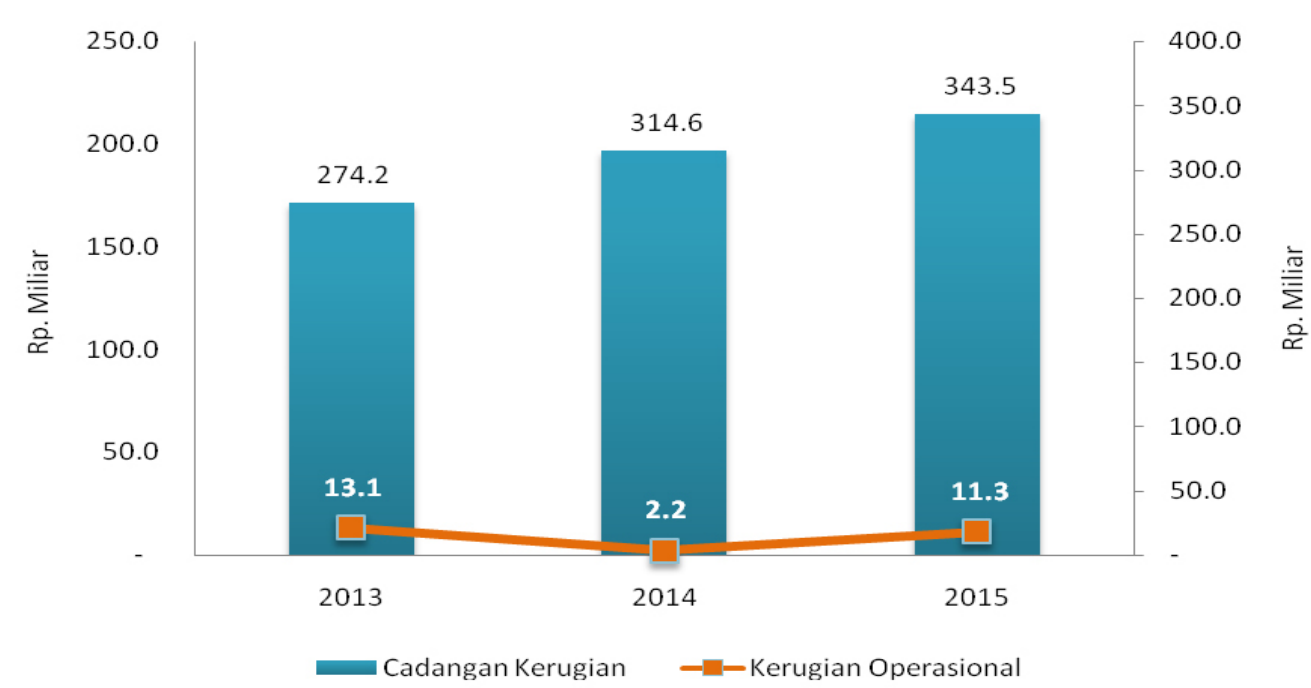

Gamber 1. Perbandingan cadangan modal dan kerugian operasional bank syariah xyz 


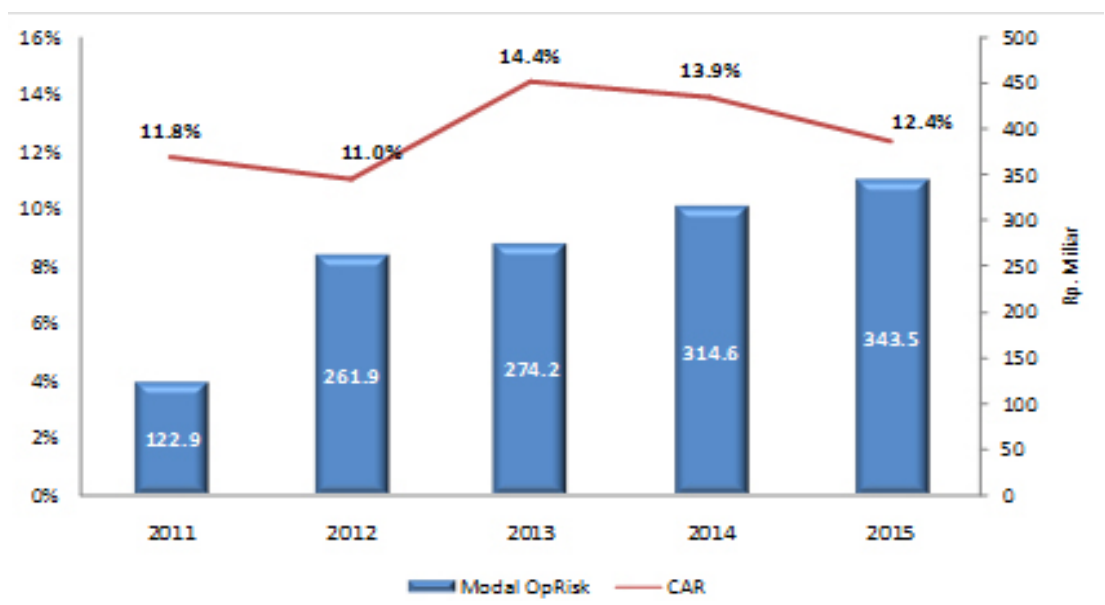

Gambar 2. Cadangan modal risiko operasional terhadap CAR Bank Syariah XYZ

Beberapa penelitian terdahulu yang telah dilakukan antara lain, Gustina (2005) dalam penelitiannya berjudul "Pengukuran risiko operasional Bank XYZ Syariah dengan menggunakan metode Advanced Measurement Approach" menggunakan metode analisis Actuarial model, menyimpulkan bahwa hasil perhitungan menunjukan nilai VaR dari kejadian human dan proses yang hampir mendekati nilai Annual Loss Distribution. Martin (2009) dalam penelitiannya yang berjudul "Comparative Analysis of Operational Risk Approaches Within Basel Regulatory Frame Work: Case Study of Spanish Saving Bank" membandingkan metode AMA melalui pendekatan LDA menekankan pada analisis kerugian operasional yang membutuhkan data historis kejadian risiko operasional dengan menerapkan konsep VaR. Penelitiannya menggunakan teknik simulasi Monte carlo dalam menentukan aggregate loss distribution. Distribusi total kerugian kemudian digunakan untuk memproyeksikan potensi kerugian risiko operasional. Penelitian lain mengenai pengukuran risiko operasional terdapat pada jurnal yang ditulis oleh Barreira et al. (2009) yang berjudul “ $A$ practical Approach to Model Banking Risks using Loss Distribution Approach (LDA) in Basel II Framework", memaparkan AMA sebagai salah satu metode penting untuk menghitung cadangan risiko perusahaan. Salah satu metode yang umum. Namun, memiliki kerumitan adalah LDA. Loss Profile dapat menggambarkan entitas suatu perusahaan. Jika data yang terkumpul selama tiga sampai lima tahun telah cukup, maka LDA dapat digunakan, tetapi tanpa estimasi parameter melainkan sesuai dengan fungsi distribusi yang ada.
Pencatatan data kerugian operasional di bank syariah xyz diketahui masih dalam tahap implementasi pengumpulan data risiko operasional serta sistem informasi bagi manajemen risiko operasionalnya, namun sejak dibentuknya departemen khusus manajemen risiko operasional, saat ini seluruh data kerugian operasional sudah dilakukan validasi untuk memastikan pencatatan kerugian operasional telah benar dan akurat serta telah sesuai dengan pemetaan faktor penyebab dan tipe kejadian menurut standar basel.

Berdasarkan histori data kerugian operasional pada Tabel 1, nilai kerugian tertinggi terjadi di tahun 2013 dan 2015. Lebih dari 80\% (Rp10,5 miliar) pada tahun 2013 dikontribusi dari Business Disruption \& System Failure dan lebih dari 90\% (Rp10,2 miliar) pada tahun 2015 dikontribusi dari kejadian internal fraud. Akkizidis dan Kumar (2008) mengatakan bahwa jumlah terbesar dari kerugian operasional berasal dari kegiatan yang disengaja seperti penyelewengan (fraud) dan transaksi olehpihakyangtidakberwenang (unauthorizedtrading). Disebutkan oleh Marshall (2001) bahwa operational risk as including system failure, system disruption, and system compromises. Risiko operasional itu adalah kerugian besar disebabkan oleh kelemahan sistem, sumber daya manusia yang mengelola operasional perusahaan dan kegagalan sistem dalam mencatat atau memproses seluruh transaksi perusahaan sehingga timbul yang disebut error, serta adanya kecurangan yang disebabkan dari hasil kejahatan internal maupun eksternal. 
Tabel 1. Kerugian risiko operasional per kategori kejadian

\begin{tabular}{lccccccccc}
\hline \multirow{2}{*}{ Event Type } & \multicolumn{2}{c}{2013} & \multicolumn{2}{c}{2014} & \multicolumn{2}{c}{2015} & \multicolumn{2}{c}{2016} \\
\cline { 2 - 10 } & Frek & $\mathrm{Rp}$ & Frek & $\mathrm{Rp}$ & Frek & $\mathrm{Rp}$ & Frek & $\mathrm{Rp}$ \\
\hline Internal fraud & 7 & 121 & 14 & 516 & 22 & 10.235 & 4 & 53 \\
External fraud & 2 & 1.556 & 58 & 908 & 19 & 255 & 13 & 478 \\
Client, product \& business practices & 53 & 0 & 10 & 0 & 8 & 0 & 5 & 0 \\
Damage to physical assets & 15 & 191 & 26 & 190 & 12 & 1 & 9 & 1.006 \\
Business disruption \& system failure & 26 & 10.557 & 385 & 441 & 42 & 452 & 110 & 38 \\
Execution delivery \& process management & 95 & 673 & 40 & 172 & 40 & 311 & 64 & 2.204 \\
Employment practices \& workplace safety & 0 & 0 & 0 & 0 & 1 & 0 & 0 & 0 \\
Total & 198 & 13.097 & 533 & 2.226 & 344 & 11.254 & 205 & 3.778 \\
\hline
\end{tabular}

Dari Tabel 1, terlihat bahwa tingginya frekuensi kejadian risiko operasional tidak selalu diikuti dengan besarnya nilai kerugian, fluktuasi frekuensi dan nilai kerugian mengalami penurunan maupun peningkatan yang cukup signifikan. Hal tersebut bisa disebabkan karena kejadian itu sering terjadi namun berdampak rendah (high frequency low impact) atau jarang terjadi, tetapi berdampak tinggi (low impact high frequency), atau dapat pula disebabkan oleh faktor risk awareness yang masih rendah akibat kekhawatiran/ketakutan pegawai dalam mencatat kerugian yang sebenarnya terjadi akan berdampak buruk terhadap performance dan karirnya di masa depan. Oleh karena itu, pengendalian risiko operasional bersifat kompleks, karena menyangkut kesadaran risiko seluruh pegawai bank, selain itu risiko operasional juga tidak dapat diprediksi kapan akan terjadi dan berapa besar nilai kerugian yang akan ditimbulkannya.

Setiap bank memiliki karakteristik risiko operasional yang berbeda, tergantung dari histori kerugian operasional yang dialaminya, hal tersebut akan memengaruhi kesesuaian model perhitungan modal risiko operasional bila menggunakan internal model (AMA). Di sisi lain, tantangan yang dialami perbankan syariah adalah masalah keterbatasan anggaran cadangan modal (capital charge) risiko operasional, untuk itu diperlukan suatu model pendekatan perhitungan yang menghasilkan nilai yang lebih efisien serta sensitif terhadap risiko operasional. Secara teoritis pengukuran risiko operasional dengan internal model (AMA) dapat menghasilkan nilai cadangan modal minimum menjadi lebih kecil dibandingkan dengan perhitungan basic standard model (Global Association of Risk Proffesionals, 2008).

Penelitian ini bertujuan melakukan perhitungan OpVar untuk mengestimasi peluang kejadian kerugian (probability of the frequency of losses) di bank syariah xyz; menganalisis dan mengevaluasi tipe kejadian risiko operasional yang berkontribusi besar pada kerugian operasional bank syariah xyz; menentukan besarnya tingkat efisiensi beban modal risiko operasional yang didapat dengan menggunakan metode LDAAggregation.

\section{METODE PENELITIAN}

Penelitian ini dilakukan di kantor pusat bank syariah xyz di Operasional Risk Management Department Divisi Manajemen Risiko. Pengumpulan data dilaksanakan pada bulan Januari sampai dengan Oktober 2016. Penelitian dilakukan menggunakan metode kuantitatif dan menggunakan data sekunder, yaitu data kerugian operasional dan hasil temuan audit periode 1 Januari 2013 hingga 30 Juni 2016. Keunggulan data sekunder adalah dari segi penghematan waktu dan biaya dalam memperoleh data (Sekaran et al. 2010). Jika data sekunder yang diperoleh cukup untuk memenuhi kebutuhan data penelitian maka biaya penelitian dapat dihemat dalam jumlah besar. Selain itu waktu untuk memperoleh data sekunder menjadi lebih singkat. Desain penelitian ini adalah penelitian deskriptif yang bertujuan untuk mendeskripsikan sesuatu, biasanya adalah karakteristik suatu fenomena atau fungsi (Cooper dan Schindler, 2008).

Data yang digunakan dalam penelitian ini merupakan data sekunder. Data yang digunakan bersumber dari manajemen insiden yang terdapat di aplikasi Operational Loss Data Collection (OLDC) serta dikombinasikan dengan data yang dikumpulkan dari berbagai sumber, meliputi data kerugian yang dikelola oleh operation dan supporting unit serta data temuan internal audit yang belum di input dalam aplikasi 
OLDC. Data yang digunakan dalam penelitian ini berupa data frekuensi kerugian dan data severitas yang merupakan database atas seluruh kerugian finansial akibat risiko operasional di seluruh unit kerja bank (457 unit kerja) baik itu operasional bisnis unit (404 unit cabang) maupun supporting unit di kantor pusat (53 unit kerja) selama tiga setengah tahun mulai dari 1 Januari 2013 hingga 30 Juni 2016.

Variabel yang digunakan dalam penelitian ini berdasarkan pada penilaian profil risiko yang terdiri dari penilaian inherent risk (risiko yang melekat pada aktivitas bank) dan penilaian risk control system (pengendalian terhadap risiko inherent) pada tujuh kategori kejadian, yaitu internal fraud, external fraud, employment practices and workplace safety, clients products and business practices, damage to physical asets, business disruption and system failures, dan execution delivery and process manajement (Bank for International Settlement, 2001).

Desain penelitian ini adalah penelitian deskriptif, menurut Cooper dan Schindler (2008) penelitian deskriptif bertujuan mendeskripsikan sesuatu, biasanya adalah karakteristik suatu fenomena atau fungsi. Variabel yang digunakan berdasarkan pada penilaian profil risiko yang terdiri dari penilaian inherent risk (risiko yang melekat pada aktivitas bank) dan penilaian risk control system (pengendalian terhadap risiko inherent).

Terdapat beberapa metode pengukuran risiko operasional sebagaimana disarankan oleh lembaga keuangan internasional Bank for International Settlement (Djuraidah et al. 2011), yaitu Basic Indicator Approach (BIA), Standardized Approach (SA) dan Advanced Measurement Approach (AMA). Menurut Muslich (2007) dan Bee (2006), terdapat beberapa jenis model pendekatan dalam metode AMA, yaitu Loss Distribution Approach (LDA) dengan Actuarial dan Aggregated, Bootstrapping Approach, Bayesian Approach dan Extreme Value Theory (EVT). Penelitian ini menggunakan LDA-Aggregated model, dimana pendekatan perhitungan modal risiko didasarkan pada data histori kerugian operasional yang dikelompokkan dalam tujuh jenis tipe kejadian (events types). Chernobai et al. (2007) mengatakan dengan menggunakan LDA, bank dapat mengukur distribusi frekuensi serta seberapa besar kerugian operasional untuk setiap tipe kejadian (event types) dalam jangka waktu satu tahun. Esterhuyen et al. (2008) dan Angela et al. (2009) berpendapat bahwa LDA merupakan model yang paling akurat dalam menghitung risiko operasional untuk sebagian besar bank.

Langkah awal yang dilakukan adalah mengelompokkan data kerugian operasional menjadi data frekuensi dan data severitas, dimana kedua kelompok data bersifat independent satu dengan lainnya (Peters et al. 2007). Kemudian dilakukan penentuan jenis distribusi keduanya berdasarkan data yang ada. Untuk menguji akurasi distribusi yang dipilih akan dilakukan melalui tes Goodness of Fit (GoF), yaitu prosedur statistik untuk mengetahui apakah distribusi kerugian yang diasumsikan itu memang benar sebagaimana yang diasumsikan. Namun, terdapat beberapa isu terkait fitting distribusi antara lain pengumpulan data tidak lengkap, pemotongan dan minimnya pengaturan data (Peters dan Sisson, 2006). Tes GoF merupakan tes dengan menggunakan pengujian Chi-square test berdasarkan data probability distribution function (pdf). Berdasarkan pdf dari distribusi yang diasumsikan akan dihitung nilai chi-square-nya untuk dibandingkan dengan nilai chi-square test statistik. Jika nilai chisquare dari distribusi yang diasumsikan lebih kecil dari nilai chi-square tes statistik maka distribusi yang diasumsikan benar (Muslich, 2007). Tes GoF dilakukan dengan menggunakan bantuan software EasyFit 5.6 dan aplikasi spreadsheet Excel.

Setelah mengetahui fit sebaran dari distribusi frekuensi dan distribusi severitas, selanjutnya akan dilakukan simulasi Monte Carlo. Menurut Fontnouvelle et al. (2004), Frachot et al. (2001) dan Martin (2009), kombinasi dua distribusi frekuensi dan severitas tersebut akan menghasilkan suatu distribusi baru yang disebut Aggregated Loss Distribution, yang selanjutnya akan digunakan untuk menghitung perkiraan VaR. Var digunakan untuk mengantisipasi kondisi bisnis bank yang tak terduga di masa depan (Ismal, 2010). Tahapan ini dikenal juga dengan metode Aggregated VaR. Langkah yang dilakukan dalam aggregated loss distribution adalah membuat running number sebanyak yang diinginkan. Untuk memperoleh optimum VaR, akan ditentukan running number simulasi. Semakin banyak simulasi yang dilakukan akan semakin akurat hasil yang didapat. Running number ini digunakan untuk menentukan nilai Operational Value at Risk (OpVaR), urutan data keberapa yang akan diambil sebagai perkiraan nilai VaR akan disesuaikan dengan tingkat keyakinan yang diinginkan. Dalam penelitian ini running number yang akan dilakukan sebanyak 10.000 
dengan tingkat keyakinan 99,9\%. Langkah selanjutnya adalah menentukan probabilitas untuk frekuensi dan severitas. Menurut Fontnouvelle et al. (2004), proses Frequency of Aggregated Loss Distribution dilakukan untuk menghasilkan probabilitas frekuensi distribusi Poisson dengan melakukan pemodelan di spreadsheet excel pada menu Tools, Data Analysis, Random Number Generation menggunakan nilai parameter Poisson. Hasil dari proses Frequency of Aggregated Loss Distribution merupakan nilai estimasi peluang terjadinya kejadian (event) setiap bulan selama periode data kerugian operasional. Sedangkan proses Severity of Aggregated Loss Distribution, dilakukan untuk nilai probabilitas severitas hasil dari uniform random numbers yang sesuai dengan frekuensi, dihasilkan dari proses pengulangan sebanyak jumlah maksimal nilai frekuensi distribusi Poisson yang didapat. Selanjutnya dalam setiap kejadian (event) dicari nilai severitasnya dengan menggunakan rumus di spreadsheet excel sesuai dengan distribusi yang fit, misalnya jika severity of loss distribution yang fit adalah distribusi $\mathrm{L}$ ognormal maka fungsi excel yang digunakan adalah fungsi "loginv (probability, location or mean, scale parameter or standard deviation)", atau apabila severity of loss distribution yang fit adalah distribusi Eksponential maka menggunakan rumus: $(1-\rho) / \lambda$. Hasil proses Severity of Aggregated Loss Distribution merupakan estimasi besarnya nilai severitas rata-rata setiap bulan selama periode data kerugian operasional.

Perhitungan beban modal risiko operasional dilakukan menggunakan Aggregated Loss Distribution dari hasil simulasi Monte Carlo. Nilai probabilitas severitas dari setiap baris running number dijumlahkan, kemudian hasil penjumlahan diurutkan mulai dari nilai severitas terbesar hingga nilai severitas terkecil, begitu pula nilai persentase tingkat keyakinan (percentile) dilakukan pengurutan yang sama. Total severitas pada urutan baris yang sesuai dengan percentile 99,9\% (tingkat kepercayaan) digunakan sebagai perkiraan nilai OpVaR. Kemudian nilai OpVaR dari setiap tipe kejadian dijumlahkan sehingga diperoleh nilai total OpVaR. Nilai total OpVaR inilah yang digunakan sebagai nilai capital charges.

Untuk memastikan apakah model yang digunakan sudah valid maka dilakukan uji validitas model (back testing) yang dalam penelitian ini menggunakan metode Proportion of Failures (Kupiec Test). Menurut Perez (2011) dan Muslich (2007), langkah pengujian validitas model ini antara lain menentukan besarnya
VaR kerugian operasional dari waktu ke waktu sesuai dengan periode proyeksinya, lalu menentukan besarnya kerugian operasional riil dalam periode yang sama dengan periode proyeksi, kemudian menentukan binary indicator dengan ketentuan jika value at risk kerugian operasional lebih besar daripada angka kerugian operasional riil, maka nilai binary indicator adalah 0 , jika sebaliknya maka nilai binary indicator adalah 1 . Kemudian, nilai binary indicator dijumlahkan menjadi jumlah failure rate, Kemudian tentukan nilai tingkat keyakinan, misalnya 1 - $\alpha=99,9 \%$ dan besarnya tingkat failure rate yang diharapkan pada nilai $\alpha$. Langkah akhir adalah menghitung Loglikelihood Ratio (LR) dengan cara menghitung jumlah kesalahan (failure rate) yang terjadi dibandingkan dengan jumlah data menggunakan rumus:

$$
L R=-2 \ln \left[(1-\propto)^{T-V}(\propto)^{V}\right]+2 \ln \left\{\left[1-\frac{V}{T}\right]^{T-V}\left(\frac{V}{T}\right)^{V}\right\}
$$

Keterangan: LR(Loglikelihood Ratio); $\alpha$ (probabilitas kesalahan di bawah hipotesis nol); V (jumlah kesalahan estimasi); $\mathrm{T}$ (jumlah data observasi).

Jika jumlah failure rate lebih kecil ddibandingkan tingkat failure rate yang diharapkan, maka model risiko operasional valid untuk digunakan dalam proyeksi atau dengan membandingkan nilai LR terhadap nilai kritis chi-square dengan derajat kebebasan 1 pada tingkat signifikansi yang diharapkan. Jika nilai LR lebih kecil dibandingkan dengan nilai kritis chi-square maka model perhitungan risiko tersebut valid dan sebaliknya. Berdasarkan landasan teori dan alur berpikir yang dijelaskan diatas maka dapat dibuat ringkasan kerangka pemikiran penelitian seperti pada Gambar 3.

\section{HASIL}

Untuk melakukan pemodelan dan pengukuran potensi kerugian operasional harus diketahui terlebih dahulu karakteristik dari distribusi kerugian operasional. Distribusi data kerugian risiko operasional dikelompokkan ke dalam distribusi frekuensi dan distribusi severitas. Distribusi frekuensi menunjukan jumlah terjadinya kejadian risiko operasional dalam periode waktu tertentu tanpa melihat besaran nilai kerugian. Distribusi frekuensi Poisson merupakan distribusi yang paling banyak terjadi karena karakteristiknya paling sederhana dan paling sesuai yang mencerminkan probabilitas jumlah atau frekuensi terjadinya kerugian operasional (Muslich, 2007). Rata- 
rata jumlah atau frekuensi kejadian dapat dinyatakan dengan $\lambda$ (lambda) dalam suatu periode tertentu.

Hasil tes GoF distribusi sebaran poisson data frekuensi, didapatkan nilai chi-square dari distribusi yang diasumsikan lebih kecil dari nilai chi-square tes statistik maka distribusi yang diasumsikan benar. Tabel 2 menjelaskan fit distribusi sebaran poisson data frekuensi kerugian operasional bank syariah xyz.

Kategori tipe kejadian internal fraud memiliki rata-rata kejadian risiko operasional setiap bulannya sebanyak 1 kali, external fraud memiliki rata-rata kejadian risiko operasional sebanyak 2 kali, employment practices \& workplace safety memiliki nilai rata-rata kejadian risiko operasional sebanyak 0,02 kali setiap bulannya client, product \& business practices memiliki ratarata kejadian risiko operasional sebanyak 1,8 kali setiap bulannya, damage to physical assets memiliki rata-rata kejadian risiko operasional sebanyak 1,5 kali setiap bulannya, business disruption \& system failure memiliki rata-rata kejadian risiko operasional sebanyak 18 kali setiap bulannya, execution delivery \& process management memiliki rata-rata kejadian risiko operasional sebanyak 5,7 kali setiap bulannya.

Untuk menentukan distribusi severitas kerugian operasional yang fit, pendekatan pertama yang dilakukan adalah memilih kelompok umum dari distribusi probabilitas severitas, kemudian menetapkan nilai parameter yang paling cocok dengan data severitas kerugian yang di observasi, lalu dilakukan tes GoF distribusi severitas. Tabel 3 menjelaskan hasil tes GoF distribusi severitas kerugian operasional bank syariah xyz.

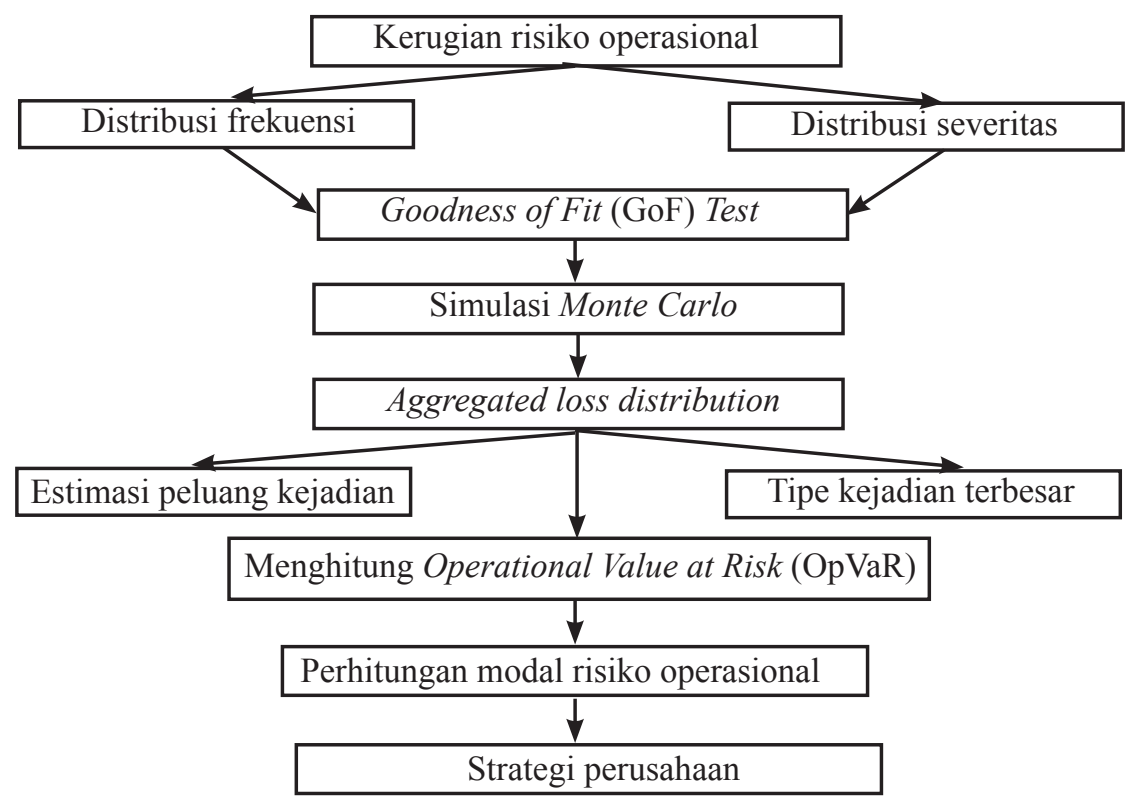

Gambar 3. Kerangka pemikiran penelitian

Tabel 2. Parameter distribusi sebaran poisson data frekuensi

\begin{tabular}{lccccccc}
\hline & \multicolumn{7}{c}{ Tipe kejadian } \\
\cline { 2 - 7 } Distribusi & $\begin{array}{c}\text { Internal } \\
\text { fraud }\end{array}$ & $\begin{array}{c}\text { External } \\
\text { fraud }\end{array}$ & $\begin{array}{c}\text { Praktek } \\
\text { ketenaga- } \\
\text { kerjaan }\end{array}$ & $\begin{array}{c}\text { Klien } \\
\text { produk }\end{array}$ & $\begin{array}{c}\text { Kerusakan } \\
\text { fisik aset }\end{array}$ & $\begin{array}{c}\text { Gangguan } \\
\text { bisnis }\end{array}$ & $\begin{array}{c}\text { Eksekusi } \\
\text { pengiriman }\end{array}$ \\
\hline Poisson & $\lambda=1,119$ & $\lambda=2,1905$ & $\lambda=0,02381$ & $\lambda=1,8095$ & $\lambda=1,4762$ & $\lambda=18,167$ & $\lambda=5,6905$ \\
\hline
\end{tabular}

Tabel 3. Distribusi sebaran peluang data severitas kerugian operasional

\begin{tabular}{llllllll}
\hline \multirow{2}{*}{ Distribusi } & \multicolumn{1}{c}{$\begin{array}{c}\text { Internal } \\
\text { fraud }\end{array}$} & $\begin{array}{c}\text { External } \\
\text { fraud }\end{array}$ & $\begin{array}{c}\text { Praktek } \\
\text { ketenaga- } \\
\text { kerjaan }\end{array}$ & $\begin{array}{c}\text { Klien } \\
\text { produk }\end{array}$ & $\begin{array}{c}\text { Kerusakan } \\
\text { fisik aset }\end{array}$ & $\begin{array}{c}\text { Gangguan } \\
\text { bisnis }\end{array}$ & $\begin{array}{c}\text { Eksekusi } \\
\text { pengiriman }\end{array}$ \\
\hline Generalized & $\kappa=0,96176$ & $\kappa=0,73268$ & - & - & $\kappa=0,95272$ & $\kappa=0,98184$ & $\kappa=0,93204$ \\
pareto & $\sigma=8,67$ & $\sigma=22,601$ & & & $\sigma=1,5978$ & $\sigma=5,0059$ & $\sigma=5,6025$ \\
& $\mu=-3,8915$ & $\mu=-8,4519$ & & $\mu=-0,7486$ & $\mu=-2,1802$ & $\mu=-2,4423$ \\
\hline
\end{tabular}


Distribusi data severitas internal fraud, external fraud, damage to physical assets, business disruption \& system failure, execution delivery \& process management adalah menyebar Generalized Pareto Distribution (GPD). Lee et al. (2010) dan Agostini (2007) mengatakan distribusi GPD memiliki karekteristik jarang terjadi dan jika terjadi mempunyai konsekuensi nilai kerugian operasional yang besar. Menurut Fontnouvelle, Rosengren dan Jordan (2004), distribusi severitas dibedakan menjadi distribusi dengan smooth tail untuk fungsi seperti Wiebull, Lognormal, Gamma, Exponential dan distribusi dengan heavy tail untuk fungsi Pareto, Generalized Pareto, Burr, Log-Logistic, Log-Gamma.

\section{Perhitungan Operational Value at Risk (OpVaR)}

Setelah proses uji GoF data frekuensi dan severitas dilakukan, selanjutnya dilakukan simulasi Monte Carlo untuk menghasilkan Aggregated Loss Distribution yang digunakan untuk menghitung nilai OpVar. Tabel 4 menunjukkan data hasil perhitungan OpVaR dari masing-masing tipe kejadian dengan derajat kepercayaan $99,9 \%$.

Tabel 4. Nilai Operational Value at Risk (OpVaR)

\begin{tabular}{lr}
\hline \multicolumn{1}{c}{ Tipe kejadian } & \multicolumn{1}{c}{ OpVaR } \\
\hline Internal fraud & 47138,00 \\
External fraud & 37470,52 \\
Client, product \& business practices & 0,00 \\
Employment practices \& workplace safety & 0,00 \\
Damage to physical assets & 8688,26 \\
Business disruption \& system failure & 128328,45 \\
Execution delivery \& process management & 59036,57 \\
\hline Total & 280661,80 \\
\hline
\end{tabular}

DarihasilperhitungannilaiOpVaratas tujuhtipekejadian risiko operasional bank syariah xyz didapatkan tiga tipe kejadian yang memiliki kontribusi kerugian operasional terbesar, yaitu business disruption \& system failure, execution, delivery \& process management, dan internal fraud, dimana penyebab utamanya adalah kegagalan sistem dan kesalahan manusia. Kegagalan sistem dipicu dari adanya penggantian core banking system yang belum stabil namun sudah diimplementasikan ke seluruh cabang di Indonesia sejak bulan Maret 2013. Dampak yang terjadi meliputi kompleksitas teknologi informasi yang menghubungkan core banking system dengan branch delivery system, financing origination system, E-Channels, dan core banking support system. Kegagalan sistem teknologi informasi yang terjadi pada bulan Juni 2016 berada pada kategori high akibat adanya sistem core banking/payment system/sistem core channel yang tidak berfungsi atau mengalami gangguan selama $\geq 4$ jam. Di samping itu, kerentanan sistem teknologi informasi terhadap ancaman dan serangan virus juga menjadi masalah gangguan bisnis dan kegagalan sistem. Berdasarkan laporan status tindak lanjut, serangan virus dengan kategori tindakan cleaned sebanyak 23.212 varian, quarantined sebanyak 230.313 varian, dan pending repair sebanyak 898 varian. Untuk mengatasi masalah tersebut, bank perlu meningkatkan kualitas penerapan manajemen risiko operasional yang antara lain pertama, peran aktif dan pengawasan manajemen atas performance IT dan infrastruktur pendukung melalui forum IT Steering Committee. Kedua, bank melakukan redesign middleware sebagai langkah mitigasi permasalahan downtime yang terjadi pada core system dan payment system. Ketiga, secara periodik IT Group menginformasikan perkembangan status insiden priority 1 dan 2 kepada unit terkait dalam bentuk email IT Incident Update sebagai bentuk tindak lanjut atas penyelesaian insiden tersebut. Keempat, secara periodik bank melakukan evaluasi terhadap ketersedian jaringan IT, ketersedian layanan ATM, core banking system, dan payment system melalui Key Risk Indicator IT Group.

\section{Analisis dan Mengevaluasi Tipe Kejadian Risiko Operasional}

Pengujian validitas model (back testing) dilakukan untuk mengetahui akurasi model risiko operasional yang digunakan dalam memproyeksi potensi kerugiannya, yaitu dengan membandingkan nilai value at risk risiko operasional dengan reaslisasi kerugian operasional dalam suatu periode waktu tertentu (Muslich, 2007). Hasil uji back testing dengan menghitung nilai Loglikelihood Ratio (LR) pada setiap jenis kejadian dijelaskan pada Tabel 5.

Hasil uji back testing dapat disimpulkan untuk masingmasing hasil perhitungan, mendapatkan nilai LR yang lebih kecil dari chi-square cv tabel dengan derajat bebas 1 dan alpha $1 \%$, yaitu sebesar 9,2103 maka Ho diterima. Artinya, model perhitungan risiko dapat dikatakan fit atau valid. Dari hasil uji pada Tabel 4, mengindikasikan bahwa sebaran model yang diperoleh sudah mampu menjelaskan kondisi data. 
Kerugian risiko operasional disebabkan oleh empat faktor yaitu proses internal yang kurang memadai, kegagalan proses internal, kesalahan manusia, kegagalan sistem, dan/atau adanya kejadian eksternal (PBI, 2011). Penelitian terdahulu menunjukkan bahwa penyebabutama kerugian operasional perbankan syariah ada pada masalah sistem dan manusia (Akkizidis dan Kumar, 2008; Marshall, 2001).

Estimasi peluang kejadian dengan tingkat kepercayaan 99,9\% yang digunakan, berarti bahwa dengan probabilitas $99,9 \%$ kerugian risiko operasional maksimum akibat business disruption and system failures yang dihadapi bank syariah xyz selama 1 tahun kedepan adalah sebesar Rp128,33 miliar dengan frekuensi rata-rata setiap bulan terjadi 18 kali. Untuk execution delivery \& process management dengan probabilitas $99,9 \%$, kerugian risiko operasional maksimum yang dihadapi bank syariah xyz selama 1 tahun kedepan adalah sebesar Rp59,04 miliar dengan frekuensi rata-rata setiap bulan terjadi 6 kali. Internal fraud dengan probabilitas $99,9 \%$, kerugian risiko operasional maksimum yang dihadapi bank syariah xyz selama 1 tahun kedepan adalah sebesar Rp59,04 miliar dengan frekuensi rata-rata setiap bulan terjadi 1 kali.

Simulasi perhitungan risiko operasional bank syariah xyz dengan menggunakan basic indicator approach menghasilkan capital charge untuk risiko operasional pada akhir tahun 2015 sebesar Rp343,50 miliar. Perhitungan beban modal risiko operasional dengan metode LDA-Aggregate dengan tingkat keparcayaan 99,9\% menghasilkan capital charge sebesar Rp280,66 miliar, angka tersebut adalah total nilai OpVaR dari seluruh tipe kejadian (Muslich, 2007). Angka ini masih lebih rendah Rp62,84 miliar dibandingkan dengan perhitungan metode BIA per laporan keuangan 2015. Dengan demikian, perhitungan risiko operasional bank syariah xyz dengan menggunakan Metode LDAAggregate menghasilkan beban modal yang lebih rendah dibandingkan dengan penggunaan metode Basic Indicator Approach. Beban modal yang lebih rendah tersebut mengimplikasikan alokasi modal yang dibutuhkan untuk menutup risiko operasionalnya menjadi lebih efisien. Hal tersebut berakibat pada kesempatan yang lebih luas bagi bank syariah xyz untuk berekspansi dan mengembangkan strategi bisnis. Selain itu, gambaran risiko operasional yang diberikan oleh metode LDA-Aggregate kiranya lebih akurat karena dalam perhitungannya menggunakan data kerugian risiko operasional bank syariah xyz yang lebih relevan dibandingkan dengan gross income.

\section{Tingkat Efisiensi Beban Modal Risiko Operasional}

Dari hasil perhitungan menggunakan metode LDA, peneliti mendapati bahwa alokasi modal risiko operasional adalah sebesar Rp280,66 miliar, angka ini masih lebih rendah Rp62,84 miliar dibandingkan dengan perhitungan metode BIA per laporan keuangan 2015, yaitu sebesar Rp343,50 miliar. Hal ini mengindikasikan bahwa perhitungan modal risiko operasional menggunakan model LDA-Aggregation dapat dijadikan optimisme alternatif solusi bagi peningkatan efisiensi perhitungan beban modal risiko operasional bank syariah xyz di kemudian hari, namun demikian proses penerapannya akan terbentur pada beberapa kendala antara lain model ini memiliki kelemahan kurang sensitifnya terhadap data extreme, perbedaan sistem akuntansi keuangan syariah dengan akuntansi konvensional, dan sedikitnya jumlah data kerugian operasional yang tersedia. Masalah keterbatasan jumlah data kerugian operasional dapat disebabkan faktor risk awareness yang masih rendah akibat kekhawatiran/ketakutan pegawai dalam mencatat kerugian yang sebenarnya terjadi akan berdampak buruk terhadap performance dan karirnya di masa depan. Untuk itu implementasi risk awareness dan penerapan Good Corporate Governance (GCG) perlu lebih ditingkatkan antara lain melalui kontrol internal, implementasi manajemen risiko, tranparansi, akuntansi dan disclosure pembiayaan, pemurnian dan audit syariah, regulasi dan pengawasan yang prudent. Manajemen perlu menjamin bahwa data kerugian operasional yang tercatat dalam database kerugian operasional sudah benar, untuk itu perlu adanya unit khusus yang melakukan monitoring, validasi dan tindaklanjut atas setiap kejadian operasional.

Tabel 5. Distribusi sebaran peluang data severitas kerugian operasional

\begin{tabular}{cccccccc}
\hline & \multicolumn{1}{c}{ Tipe kejadian } \\
\cline { 2 - 8 } Hasil & $\begin{array}{c}\text { Internal } \\
\text { fraud }\end{array}$ & $\begin{array}{c}\text { External } \\
\text { fraud }\end{array}$ & $\begin{array}{c}\text { Praktek } \\
\text { ketenaga- } \\
\text { kerjaan }\end{array}$ & $\begin{array}{c}\text { Klien } \\
\text { produk }\end{array}$ & $\begin{array}{c}\text { Kerusakan } \\
\text { fisik aset }\end{array}$ & $\begin{array}{c}\text { Gangguan } \\
\text { bisnis }\end{array}$ & $\begin{array}{c}\text { Eksekusi } \\
\text { pengiriman }\end{array}$ \\
\hline Nilai LR & 1,104 & 2,820 & 0 & & 0 & 4,147 & 0,924 \\
\hline
\end{tabular}




\section{Implikasi Manajerial}

Dari hasil perhitungan menggunakan metode LDAAggregate yang lebih rendah dibandingkan dengan metode BIA, mengindikasikan bahwa perhitungan modal risiko operasional menggunakan model LDAAggregate dapat dijadikan optimisme alternatif solusi bagi peningkatan efisiensi perhitungan beban modal risiko operasional bank syariah xyz di kemudian hari. Namun demikian, proses penerapannya terkendala pada beberapa faktor yang antara lain, model LDAAggregate memiliki kelemahan kurang sensitifnya terhadap data extreme, perbedaan sistem akuntansi keuangan syariah dengan akuntansi konvensional, dan masih sedikitnya jumlah data kerugian operasional yang tercatat.

Masalah keterbatasan jumlah data kerugian operasional dapat disebabkan beberapa faktor seperti implementasi perangkat aplikasi pencatatan kerugian operasional (OLDC) yang belum merata di seluruh unit kerja, pemahaman tentang tata cara penggunaan aplikasi pencatatan kerugian operasional, hingga kepedulian pegawai dalam mencatat data kerugian operasional yang sebenarnya terjadi kedalam aplikasi OLDC. Bila dilihat perbandingan antara durasi periode data dengan jumlah data yang ada, terlihat jelas bahwa faktor risk awareness di lingkungan pegawai masih rendah, artinya belum semua data kerugian operasional yang telah terjadi tercatat dalam aplikasi OLDC, hal ini disebabkan adanya kekhawatiran/ketakutan pegawai dalam mencatat data kerugian yang sebenarnya akan berdampak buruk terhadap performance dan karirnya di masa depan.

Manajemen perlu mendorong seluruh pegawai di seluruh lini jabatan untuk diyakinkan bahwa setiap kejadian yang menimbulkan kerugian operasional yang tercatat dalam aplikasi OLDC tidak akan menjadi temuan audit. Untuk itu diperlukan surat kesepakatan bersama diantara unit pemeriksa dan pengawasan yang menyatakan hal tersebut. Bagi unit pemeriksa dan pengawasan, adanya data rinci kejadian risiko operasional akan sangat membantu dalam melaksanakan fungsi, bentuk reward yang diberikan kepada unit kerja pencatat adalah menaikkan audit rating pada laporan hasil pemeriksaan. Namun, berlaku sebaliknya apabila ditemukan kejadian risiko operasional namun tidak dicatat dalam aplikasi OLDC akan menurunkan audit rating unit kerja tersebut.
Manajemen perlu meyakini bahwa data kerugian operasional yang tercatat dalam database kerugian operasional sudah benar dan akurat, untuk itu perlu adanya unit kerja khusus yang melakukan monitoring dan validasi atas proses tindaklanjut yang dilakukan pada setiap kejadian risiko operasional.

Implementasi risk awareness dan komitmen manajemen dalam penerapan Good Corporate Governance (GCG) yang islami perlu lebih ditingkatkan. Budaya risiko yang islami di semua lini jabatan, dalam hal ini kesadaran risiko dalam setiap insan bank syariah xyz harus disertai dengan nilai-nilai yang bersumber dari Al-Quran dan hadis. Nilai-nilai itu dapat berupa nilai keikhlasan, kebersamaan, dan pengorbanan (tadh-hiyyah). Makna keikhlasan adalah melakukan kewajiban secara maksimal (mujahadah) dengan niat yang bersih. Nilai kebersamaan bertujuan agar kepedulian terhadap sesama pegawai, saling menjaga dan mengingatkan dapat terpenuhi, sehingga tumbuhnya nilai saling memiliki terhadap bank. Sedangkan nilai pengorbanan dalam hal ini adalah seorang pemimpin harus berani berkorban untuk perusahaan, bukan memanfaatkan perusahaan untuk mencari keuntungan pribadi, seperti adanya motif kepentingan dalam penentuan pihak ketiga (vendor), menuntut fasilitas berlebihan tanpa melihat kondisi keuangan perusahaan, penetapan target tanpa memperhitungkan kemampuan bawahannya.

Tingginya nilai kerugian akibat internal fraud mempunyai dampak besar bagi bank dan nasabah, serta memicu terjadinya risiko reputasi, hal ini mengindikasikan mental dan etos kerja pegawai yang lemah di lingkungan pegawai, selain itu juga akibat lemahnya kontrol dalam pengawasan. Sanksi tegas terhadap pelaku yang melakukan penyimpangan dengan niat kesengajaan perlu diterapkan sesuai dengan ketentuan yang berlaku.

Seleksi pegawai seharusnya dilakukan melalui proses screening yang jelas. Semua kriteria dan persyaratan wajib dipenuhi sesuai dengan SOP yang berlaku, penyimpangan atas ketentuan harus diatur dengan jelas. Penyimpangan yang bersifat prinsip tidak dapat ditolerir, seperti misalnya calon pegawai beragama nonmuslim. Catatan dan track record pegawai di tempat kerja sebelumnya merupakan point penting yang harus dimiliki unit human capital dalam penentuan seleksi penerimaan. Pembekalan pengetahuan perbankan syariah bagi pegawai baru harus dilakukan sebelum pegawai mulai bekerja, agar hasil pekerjaan menjadi 
maksimal. Keahlian dan profesionalisme bagi calon pegawai pimpinan atau staf ahli harus diimbangi dengan kemampuan dan penguasaan ilmu syariah, agar dapat menjadi contoh dan teladan bagi bawahannya.

\section{KESIMPULAN DAN SARAN}

\section{Kesimpulan}

Faktor manusia dan sistem seperti banyak dibahas dalam tulisan dan penelitian terdahulu merupakan faktor paling berpengaruh besar dalam kerugian operasional perbankan syariah terbukti pula terjadi di bank syariah xyz. Penelitian ini menunjukkan bahwa kerugian terbesar terdapat pada tipe kejadian business disruption \& system failure, execution, delivery \& process management dan internal fraud, dimana ketiga tipe kejadian banyak disebabkan oleh faktor sistem dan kesalahan manusia baik dengan unsur kesengajaan (90\% kerugian tahun 2015) maupun tanpa kesengajaan atau kelalaian. Perhitungan risiko operasional bank syariah xyz dengan menggunakan Metode LDA-Aggregate menghasilkan beban modal yang lebih rendah dibandingkan dengan penggunaan metode basic indicator approach. Beban modal yang lebih rendah tersebut mengimplikasikan alokasi modal yang dibutuhkan untuk menutup risiko operasionalnya menjadi lebih efisien. Hal tersebut berakibat pada kesempatan yang luas bagi bank syariah xyz untuk berekspansi dan mengembangkan strategi bisnis. Selain itu, gambaran risiko operasional yang diberikan oleh metode LDA-Aggregate kiranya lebih akurat karena dalam perhitungannya menggunakan data kerugian risiko operasional bank syariah xyz yang lebih relevan dibandingkan dengan gross income. Secara keseluruhan dapat disimpulkan dari penelitian ini bahwa Metode LDA-Aggregate dapat dijadikan metode alternatif untuk mengukur risiko operasional bank syariah xyz.

\section{Saran}

Perhitungan model LDA-Aggregate terbukti menghasilkan alokasi perkiraan capital charge risiko operasional bagi bank syariah xyz yang lebih efisien dibandingkan dengan menggunakan pendekatan BIA. Namun demikian, penerapan model LDA-Aggregate ini harus memenuhi standar regulasi yang ketat yaitu dengan melibatkan Otoritas Jasa Keuangan dalam mengevaluasi apakah model perhitungan risiko operasional ini bagi bank syariah xyz layak diterima atau tidak. Keterbatasan data kerugian operasional akan mengurangi akurasi hasil perhitungan beban risiko operasional, untuk itu disarankan agar bank syariah xyz lebih meningkatkan program risk awareness dan good corporate governance agar kekhawatiran pegawai terhadap dampak pencatatan kerugian operasional di unit kerjanya lebih terjamin, misalnya dengan melakukan koordinasi dalam bentuk kesepakatan bersama dengan unit pengawasan, internal audit dan compliance agar semua data kerugian operasional yang dicatat dalam database kerugian oeprasional tidak dianggap sebagai temuan. Namun, menjadi nilai tambah dalam hasil rating audit. Perlu adanya penelitian lebih lanjut terkait dengan metode perhitungan 1 internal lainnya khususnya model dengan sensitivitas terhadap data extreme yang lebih baik sehingga dapa memperkaya pilihan model perhitungan beban modal risiko operasional.

\section{DAFTAR PUSTAKA}

Agostini A, Talamo P, Vecchione V. 2010. Combining operational loss data with expert opinions through advanced credibility theory. Journal of Operational Risk 5(1): 3-28. https://doi. org/10.21314/JOP.2010.070.

Akkizidis I, Kumar SK. 2008. Financial risk management for Islamic Banking and Finance. Hampshire: Palgrave Macmillan. https://doi. org/10.1057/9780230598751.

Angela C, Rosela B, Giovani M, Marco M. 2009. Advanced operational risk modeling in banks and insurance companies. Journal of investment Management and Financial Innovations 6(3): 73-83.

Bank for International Settlement. 2001. QIS 2 Operational Risk Loss Data. Basel. Switzerland: BCBS.

[BI] Bank Indonesia. 2009. Surat Edaran Bank Indonesia Nomor 11/3/DPNP tahun 2009 tentang Perhitungan Aset Tertimbang Menurut Risiko (ATMR) untuk Risiko Operasional dengan Menggunakan Pendekatan Indikator Dasar (PID). Jakarta: BI.

Barreira R, Tristan P Qi T. 2009. A practical approach to model banking risks using Loss Distribution Approach (LDA) in Basel II framework. Journal of Applied Economice Sciences 4(10): 483-493. https://doi.org/10.2139/ssrn.1503353. 
Bee M. 2006, Estimating and simulation loss distribution with incomplete data. Journal of Oprisk and Compliance 7(7): 483-493.

Chernobai A, Menn C, Truck S, Rachev ST. 2004. A note on the estimation of the frequency and severity distributions of operational losses. Journal of Applied Probability Trust 1(1):13-27.

Cooper DR, Schindler PS. 2008. Business Research Methods 9th Ed. New York: McGraw Hill

Djuraidah A, Pika S, Aris Y. 2011. Analisis risiko operasional bank dengan metode teori nilai ekstrim. Statistika 11(2): 115-126.

Esterhuyen J T, Paul S, Gary V V. 2008. Calculating operational value at risk (OpVar) in retail bank. Journal Sajem 11(1): 1-16.

Fontnouvelle P, Rosengren E, Jordan J. 2004. Implication of alternative operational risk techniques. Working Paper Federal Reserves Bank of Boston.

FrachotA, Georges P, RoncaliT.(2001).Loss distribution approach for operational risk. Working Paper. https://doi.org/10.2139/ssrn.1032523.

Gustina. 2005. Pengukuran risiko operasional Bank XYZ Syariah dengan menggunakan metode advanced measurement approach [tesis]. Jakarta: Universitas Indonesia.

Global Association of Risk Proffesionals dan Badan Sertifikasi Manajemen Risiko. 2008. Indonesia Certificate in Banking Risk and Regulation Workbook Level 2. London: GARP.

Gourieroux C, Laurent J P, Scaillet O. 2000. Sensitivity analysis of value at risk. Journal of Empirical Finance 7(3-4): 225-245. https://doi. org/10.1016/S0927-5398(00)00011-6.

Hafidhuddin D, Tanjung H. 2003. Manajemen Syariah dalam Praktik. Jakarta: Gema Insani.

Islamic Financial Services Board. 2005. Guiding principles of risk management for institutions (other than insurance institutions) offering only islamic financial services. http://www.ifsb.org/ standard/ifsb1.pdf [10 Juli 2016].
Ismal R. 2010. Volatility of the Returns and Expected Losses of Islamic Bank Financing, Case of Indonesia 2000-2008. Journal of Islamic and Middle Eastern Finance and Management 3(3): $1-11$.

Izhar H, Asutay M. 2010. A Theoretical analysis of the operational risk framework in Islamic Banks, IIUM Journal of Economics and Management. 18(1): 73-113.

Kuhn R, Peter N. 2002. Functional correlation approach to operational risk in banking organization. Journal of Science Direct 322(2003): 650-666.

Lee WC, Fang C J. 2010. The measurement of capital for operational risk in Taiwanese commercial banks. The Journal of Operational Risk 5(2): 79-102. https://doi.org/10.21314/JOP.2010.076.

Martin JL. 2009. Comparative anlysis of operational risk approaches within Basel regulatory framework : case study of Spanish Saving Bank. Journal of Finanacial and Analysis 22: 1-15.

Marshall C L. 2001. Measuring \& Managing Operational Risk In Financial Institution. New York: John Wiley \& Son.

Muslich M. 2007. Manajemen Risiko Operasional. Edisil. Jakarta: Bumi Aksara.

Perez R P. 2011. Testing opvar accuracy: an empirical backtesting on the loss distribution approach. Risk Journal 1(1):1-13.

Perwita A D, Nurmalina R, Affandi J. 2017. Pengaruh faktor-faktor motivasi terhadap kinerja pegawai di PT. Bank BNI Syariah kantor cabang Jakarta Barat dan Bogor. Jurnal Aplikasi Bisnis dan Manajemen 3(1): 102-112.

Peters G W, Adam M J, Arnaud D. 2007. Simulation of the annual loss distribution in operational risk via Panjer recursion and Volterra integral equations for value at risk and expected shortfall estimation. Journal of Operasional Risk 2(3): 29-58. https://doi.org/10.21314/JOP.2007.031.

Peters G, Sisson S A. 2006. Bayesian inference Monte Carlo sampling and operational risk. Journal of Operational Risk 1(3): 27-50. https://doi. org/10.21314/JOP.2006.014. 